\title{
Natural Pollen Exposure Increases the Response Plateau to Adenosine 5'-Monophosphate and Bronchial but Not Alveolar Nitric Oxide in Sensitized Subjects
}

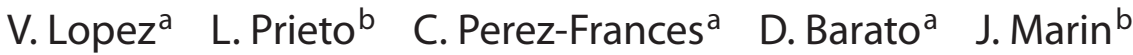 \\ ${ }^{a}$ Seccion de Alergologia, Hospital Dr. Peset, and ${ }^{b}$ Universidad de Valencia, Valencia, Spain
}

\section{Key Words}

Adenosine 5'-monophosphate $\cdot$ Airway

hyperresponsiveness - Exhaled breath condensate $\mathrm{pH}$.

Exhaled nitric oxide $\cdot$ Plateau nitric oxide concentration

\begin{abstract}
Background: The effect of allergen exposure on airway responsiveness and exhaled nitric oxide (NO) has been well documented, but no information is available on allergen-induced changes in the response plateau to adenosine $5^{\prime}$ monophosphate (AMP) and in bronchial NO flux (J'aw $\left.\mathrm{JW}_{\mathrm{NO}}\right)$ and alveolar NO ( $\left.C A_{N O}\right)$. Objectives: To determine the effect of natural allergen exposure, a proinflammatory stimulus, on the shape of the concentration-response curve to AMP and NO production in airway and alveolar sites. Methods: Airway responsiveness to high concentrations of methacholine and AMP, J'aw NO $_{\text {Ond }}$ CA $A_{N O}$ values were obtained in 31 subjects with pollen allergy and in 11 healthy controls. Subjects with pollen allergy were studied before and at the height of the pollen season whereas healthy controls were tested on one occasion only. Results: In the group with pollen allergy, natural pollen exposure increased J'aw ${ }_{N O}(p=0.03)$, but had no effect on $C A_{N O}(p=0.12)$. In the 18 subjects with pollen allergy who showed a response plateau to AMP in at least one period, the response plateau to AMP increased from a mean
\end{abstract}

of $13.4 \%$ (95\% Cl: $8.2-18.5)$ out of season to $22.5 \%$ (95\% Cl: $15.5-29.4, p=0.004)$ during the pollen season. Similar results were obtained with methacholine. Compared with healthy controls, subjects with pollen allergy had a higher response

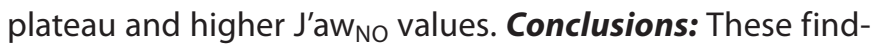
ings suggest that inflammatory changes induced by natural allergen exposure in sensitized subjects are predominantly located in the airways and associated with modifications in the shape of the concentration-response curve to direct and indirect agonists.

Copyright $\odot 2011$ S. Karger AG, Basel

\section{Introduction}

It is widely appreciated that asthma is an inflammatory disease of the airways associated with airway hyperresponsiveness. Methacholine challenge has been widely used for the detection and quantitation of airway responsiveness, and the response to this bronchoconstrictor agent is commonly expressed as the provocative concentration $\left(\mathrm{PC}_{20}\right)$ or dose $\left(\mathrm{PD}_{20}\right)$ causing a $20 \%$ fall in forced expiratory volume in $1 \mathrm{~s}\left(\mathrm{FEV}_{1}\right)$. However, airway hyperresponsiveness can be defined as the tendency of the airways to narrow too easily and too much in response to a wide variety of provoking stimuli [1]. Airway narrowing

\section{KARGER}

Fax +41613061234 E-Mail karger@karger.ch www.karger.com
(C) 2011 S. Karger AG, Basel

$0025-7931 / 12 / 0833-0225 \$ 38.00 / 0$

Accessible online at:

www.karger.com/res
Prof. Luis Prieto

Departamento de Medicina

Facultad de Medicina y Odontologia

Av. Blasco Ibáñez 15, ES-46010 Valencia (Spain)

E-Mail prieto_jes@gva.es 
that occurs too easily (airway sensitivity) is assessed by measuring $\mathrm{PC}_{20}$, but this measure does not assess excessive bronchoconstriction [2], which in some cases may lead to life-threatening attacks and which is reflected by the response plateau level. In addition, it has been suggested that the mechanisms that modulate sensitivity and the response plateau level are at least partially different [3]. Therefore, complete description of the dose-response curve requires two parameters: one for sensitivity and one for excessive bronchoconstriction (response plateau level).

Methacholine and histamine are the most frequently used spasmogens for the investigation of bronchial responsiveness. These two agonists cause bronchoconstriction by a direct effect on airway smooth muscle cells. In contrast, inhaled adenosine 5'-monophosphate (AMP) acts indirectly, causing 'primed' mast cell degranulation and the release of histamine and other mediators with subsequent smooth muscle contraction [4]. Thus, AMP may provide additional information about airway inflammation and cellular activation state in asthma [5].

On the other hand, exhaled nitric oxide (NO) levels are increased in asthma [6], and are correlated with the number of eosinophils in the lower respiratory tract [7]. Although this correlation is quite weak, exhaled NO has been proposed as a noninvasive marker of airway inflammation in asthma [8]. The plateau NO concentration measured during exhalation at the constant flow rate of $50 \mathrm{ml} / \mathrm{s}$, referred as $\mathrm{FE}_{\mathrm{NO}, 50}$, has been extensively studied as a potential index of airway inflammation. However, phenotyping asthma inflammation is a hot topic, and the interest extends beyond the identification of predominant inflammatory cells to the localization of inflammation [9] (central vs. peripheral airways). Therefore, special interest has focused on the possibility of modeling $\mathrm{NO}$ production to calculate how much of the NO that is measured in exhaled air originates from alveolar and from bronchial sources [10].

Previous investigations have demonstrated that, in sensitized subjects, natural allergen exposure (a proinflammatory stimulus) is associated with a significant increase in the response plateau to methacholine $[11,12]$ and with a significant increase in exhaled $\mathrm{FE}_{\mathrm{NO}, 50}[13,14]$. No information is available, however, on allergen-induced changes in the response plateau to AMP and in $\mathrm{CA}_{\mathrm{NO}}$ and J'aw $\mathrm{NO}_{\mathrm{NO}}$. We hypothesized that allergen exposure in sensitized subjects is associated with changes in the shape of the concentration-response curve to AMP and with possibly distinct increases in $\mathrm{CA}_{\mathrm{NO}}$ and J'awno. To confirm this hypothesis, we have identified the re- sponse plateau and NO production in bronchial and alveolar sites before and at the height of the pollen season in a group of subjects with pollen allergy.

\section{Subjects and Methods}

\section{Study Subjects}

A total of 42 subjects volunteered for this study. Thirty-one patients with seasonal allergic rhinitis, with or without intermittent asthma, were recruited from the Allergy Clinic of our institution. Asthma was diagnosed by the presence of symptoms of wheeze, breathlessness or cough plus methacholine airway hyperresponsiveness $\left(\mathrm{PC}_{20} \leq 8 \mathrm{mg} / \mathrm{ml}\right)$ or an improvement in $\mathrm{FEV}_{1}$ from a baseline of $\geq 15 \%$ after $200 \mu \mathrm{g}$ inhaled salbutamol during the pollen season. All subjects with asthma were treated with short-acting inhaled $\beta_{2}$-agonists as required. Skin prick tests showed positive responses ( $>3 \mathrm{~mm}$ wheal diameter) to grass, Olea europea and/or Parietaria judaica pollens in all the subjects. Nine subjects were also sensitized to perennial allergens although they had no symptoms out of the pollen season. A control group of 11 healthy subjects was also studied; they were recruited among volunteers in the laboratory and among students. Selection criteria for this group included no history of asthma, chronic rhinitis, atopic eczema, or other relevant disease.

All 42 subjects were nonsmokers and had baseline $\mathrm{FEV}_{1}>70 \%$ predicted. In case of recent respiratory tract infection, enrolment in the study was postponed for at least 4 weeks. The study protocol was approved by the ethics committee of Dr. Peset University Hospital and all subjects provided informed consent.

Study Design

Patients were first evaluated between mid-January and the end of February, before the pollen season had begun in Valencia, Spain. During this period, patients had 3 laboratory visits. At the first visit, all patients were evaluated for suitability and spirometry was performed. At each of the next 2 visits (3-7 days apart), spirometry and concentration-response studies with either methacholine or AMP were performed on separate days, with the order of challenge randomized. Exhaled NO was measured at the second visit. Patients returned to the laboratory at the height of the pollen season between April and June. During this period, patients attended 2 laboratory visits. At each visit, exhaled NO, spirometry and concentration-response studies with either methacholine or AMP were performed. The same determinations were performed in healthy controls on one occasion only.

The pollen season period was estimated according to atmospheric pollen counts obtained in the Valencia area [15] (fig. 1).

Study Variables

Inhalation Challenge Tests. Spirometry [16] and bronchial challenge tests [17] were performed using the dosimeter method [17] (Mefar MB3; Brescia, Italy) as previously reported [14]. Methacholine and AMP (Sigma-Aldrich, St. Louis, Mo., USA) were dissolved freshly in $0.9 \%$ saline solution to produce doubling concentration ranges of 0.39 to $100 \mathrm{mg} / \mathrm{ml}$ for methacholine and $6.25-1,600 \mathrm{mg} / \mathrm{ml}$ for AMP. The test was interrupted when a $40 \%$ decrease in $\mathrm{FEV}_{1}$ from the value obtained after saline solution administration was recorded or when the highest concentration 
Table 1. Subject characteristics and prevalence of bronchoconstriction

\begin{tabular}{lccc}
\hline Characteristics & Pollen allergy & Healthy & p value \\
\hline Subjects, $\mathrm{n}$ & 31 & 11 & \\
Diagnosis & & & \\
$\quad$ Allergic rhinitis, $\mathrm{n}$ & 20 & & 0.0002 \\
$\quad$ Allergic rhinitis + asthma, n & 11 & $31(22-40)$ & 0.98 \\
Age, years & $48(44-52)$ & $5 / 6$ & 0.86 \\
Male/female gender, $\mathrm{n}$ & $13 / 18$ & $108.0(99.4-116.5)$ & 0.08 \\
Duration of symptoms, years & $14.9(11.3-18.4)$ & $80.4(76.4-84.5)$ & \\
FEV,$\%$ predicted & $107.1(101.4-112.7)$ & $73.6(70.9-76.2)$ & \\
FEV $_{1} /$ FVC, $\%$ & &
\end{tabular}

Data are presented as means, and means and 95\% CI (in parentheses). FVC = Forced vital capacity.

was administered. A response plateau was considered to be present if 3 or more data points for the highest concentrations of agonist fell within a $5 \%$ response range. The level of the maximal $\mathrm{FEV}_{1}$ response was calculated only in those subjects who showed falls in $\mathrm{FEV}_{1}>5 \%$ and was obtained by averaging the data points on the plateau. In subjects who showed falls in $\mathrm{FEV}_{1}>40 \%$ without evidence of a plateau, the response plateau values were assigned to percent decline in $\mathrm{FEV}_{1}$ at the end of the protocol. Two subjects with a plateau during the methacholine and AMP challenges performed out of season lost the plateau during the pollen season. In these subjects, the response plateau values were assigned to percent decline in $\mathrm{FEV}_{1}$ at the end of challenge. $\mathrm{A} \mathrm{PC}_{20}$ value of $100 \mathrm{mg} / \mathrm{ml}$ for methacholine and $1,600 \mathrm{mg} / \mathrm{ml}$ for AMP was assigned to these subjects in whom $\mathrm{FEV}_{1}$ dropped $<20 \%$ even when the highest concentration of agonist was used (censored values). All $\mathrm{PC}_{20}$ values were log-transformed before analysis and are presented as geometric means. Changes in $\mathrm{PC}_{20}$ are expressed in terms of doubling concentrations of methacholine or AMP calculated as $\Delta \log \mathrm{PC}_{20} / \log 2$.

NO Measurements. Exhaled NO was measured with a chemiluminescence technique (Niox; Aerocrine, Stockholm, Sweden) according to ATS/ERS standards [18], with the exception of the choice of exhalation flow rates, which were 100, 200 and $300 \mathrm{ml} / \mathrm{s}$. To enable the subjects to achieve the target flow rate, dynamic flow resistors were used. The exhalation times varied from 6 to $10 \mathrm{~s}$, depending on the exhalation flow rate, and exhaled NO was always measured during the last $3 \mathrm{~s}$ of the exhaled NO maneuver. The average of two values performed at each of the three flow rates was recorded. The technique of Tsoukias and George [19] was used to calculate J'aw ${ }_{\mathrm{NO}}(\mathrm{pl} / \mathrm{s})$ (y intercept) and steady-state $\mathrm{CA}_{\mathrm{NO}}$ concentration (ppb) (slope) using a linear regression. $\mathrm{CA}_{\mathrm{NO}}$ was adjusted for the trumpet shape of the airway tree and axial diffusion from central to peripheral airways $\left(\mathrm{CA}_{\mathrm{NO} \text { orr }}\right)$ with the following equation [20]: $\mathrm{CA}_{\mathrm{NOcorr}}(\mathrm{ppb})=\mathrm{CA}_{\mathrm{NO}}(\mathrm{ppb})-\mathrm{J}^{\prime} \mathrm{aw}_{\mathrm{NO}}$ $(\mathrm{pl} / \mathrm{s}) / 860$.

\section{Statistical Analysis}

The primary outcome of the study was the response plateau to AMP. Secondary outcomes were the response plateau to methacholine, $\mathrm{PC}_{20}$ for $\mathrm{AMP}$ and methacholine and exhaled $\mathrm{NO}\left(\mathrm{CA}_{\mathrm{NO}}\right.$

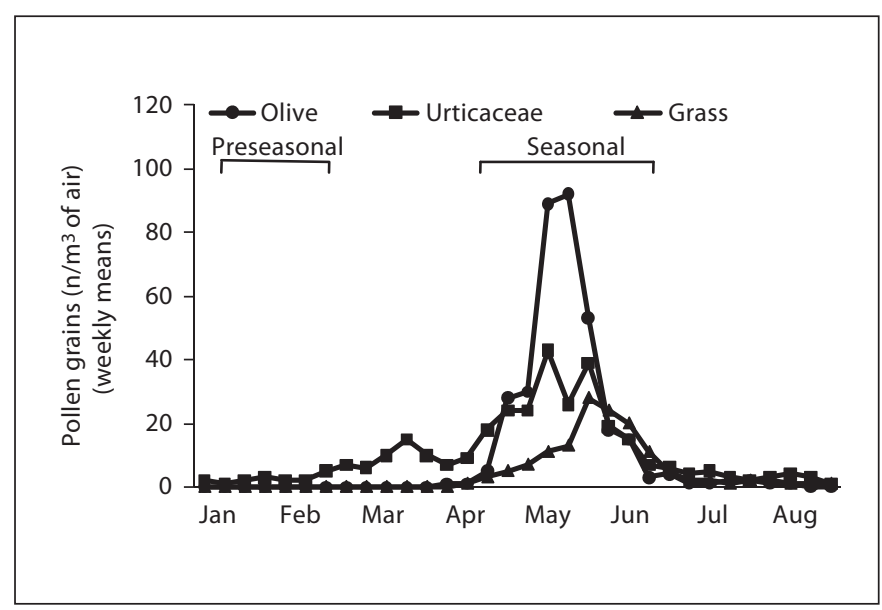

Fig. 1. Grass, urticaceae (Parietaria) and olive pollen counts between January and August 2009. The out-of-season and seasonal periods of the study are shown.

and J'aw $\mathrm{w}_{\mathrm{NO}}$ ). The sample size requirement of this study was calculated considering a difference of $7 \%$ in the response plateau to AMP as clinically relevant. Based on a calculated SD of $7 \%$ for the response plateau to AMP from previous studies [21], it was estimated that 18 patients with a plateau during at least one AMP challenge would be required to provide $80 \%$ power at the twosided 0.05 level. Given the prevalence of plateaus identified in previous studies [21], it was estimated that 30 patients would be tested to identify 18 with plateaus.

Comparisons of the characteristics of the two groups were performed by unpaired Student $t$ tests for continuous data and by Fisher exact tests for binary variables. Changes in the response plateau, $\mathrm{PC}_{20}$ and exhaled $\mathrm{NO}$ in subjects with pollen allergy were assessed by the paired t test. Correlations were explored using the Pearson correlation test. $\mathrm{p}$ values are two-sided, and values $<0.05$ were considered statistically significant. 


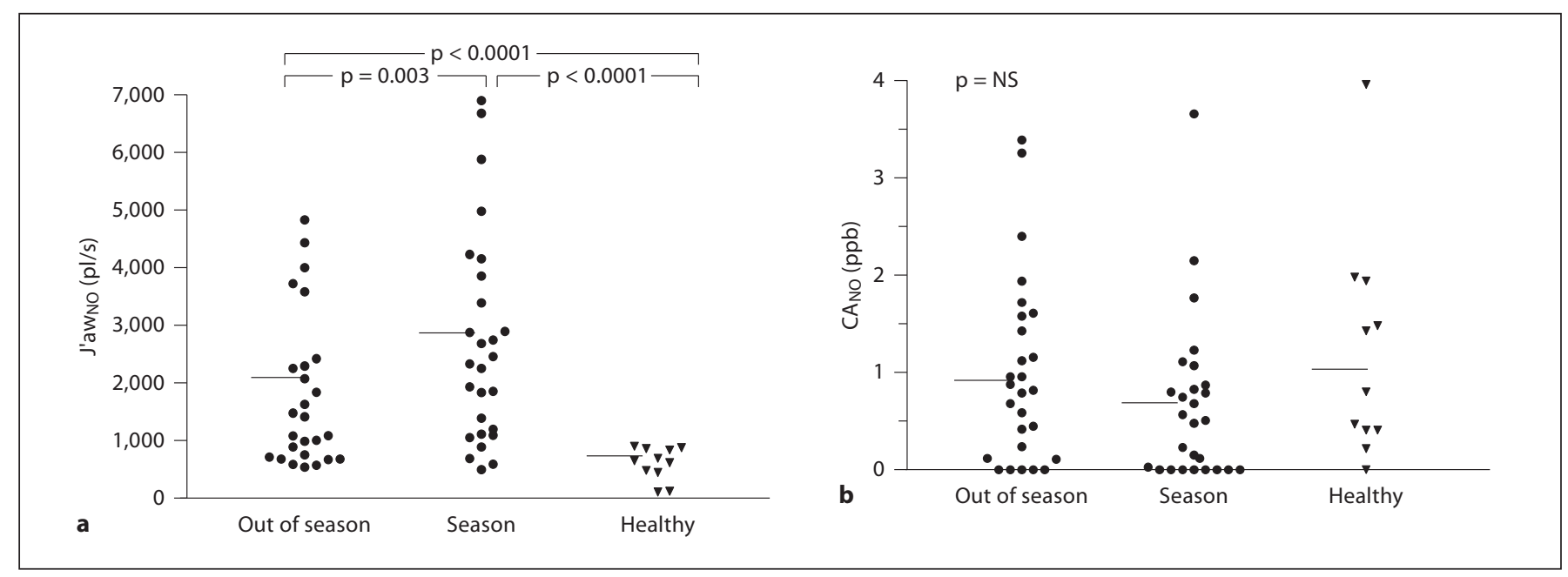

Fig. 2. Individual values for J'aw $\mathrm{w}_{\mathrm{NO}}(\mathbf{a})$ and $\mathrm{CA}_{\mathrm{NO}}$ values (b) in subjects with pollen allergy and healthy controls. Horizontal lines are means.

Table 2. Airway responsiveness and NO measurements in subjects with pollen allergy and healthy controls

\begin{tabular}{|c|c|c|c|}
\hline \multirow[t]{2}{*}{ Variables } & \multicolumn{2}{|l|}{ Pollen allergy } & \multirow[t]{2}{*}{ Healthy } \\
\hline & out of season & during season & \\
\hline \multicolumn{4}{|l|}{ Methacholine } \\
\hline $\mathrm{PC}_{20}{ }^{1}, \mathrm{mg} / \mathrm{ml}$ & $23.0(12.5-42.2)$ & $13.9(6.9-27.9)$ & $72.9(53.0-100.0)$ \\
\hline Response plateau ${ }^{2}, \%$ & $22.8(17.9-27.7)$ & $28.7(22.7-34.8)$ & $15.1(7.7-22.6)$ \\
\hline \multicolumn{4}{|l|}{ AMP } \\
\hline $\mathrm{PC}_{20} 1, \mathrm{mg} / \mathrm{ml}$ & $769.1(472.1-1,253.1)$ & $298.5(147.6-602.6)$ & $1,479.1(1,241.7-1,600.0)$ \\
\hline Response plateau ${ }^{2}, \%$ & $15.2(10.1-20.3)$ & $23.0(17.0-29.0)$ & $7.4(5.1-11.1)$ \\
\hline \multicolumn{4}{|l|}{ Exhaled NO } \\
\hline $\mathrm{J}^{\prime} \mathrm{aw} \mathrm{NO}^{2}, \mathrm{pl} / \mathrm{s}$ & $1,975(1,327-2,624)$ & $2,685(1,964-3,405)$ & $599(406-791)$ \\
\hline $\mathrm{CA}_{\mathrm{NO}}{ }^{2}, \mathrm{ppb}$ & $0.95(0.58-1.32)$ & $0.73(0.41-1.06)$ & $1.19(0.42-1.96)$ \\
\hline
\end{tabular}

\section{Results}

Subjects with pollen allergy were significantly older and tended to have lower $\mathrm{FEV}_{1} / \mathrm{FVC} \%$ values than healthy controls. The two groups were similar with regard to sex and baseline $\mathrm{FEV}_{1}$ (table 1). A total of 18 subjects with pollen allergy ( 9 with allergic rhinitis and 9 with allergic rhinitis and associated asthma) were responsive $\left(\mathrm{FEV}_{1}\right.$ fall $\left.\geq 20 \%\right)$ to methacholine whereas only 9 subjects (4 with allergic rhinitis and 5 with allergic rhinitis and asthma) were responsive to AMP. Responsiveness to AMP and methacholine was identified in 1 and 4 healthy controls, respectively.
Differences in Airway Responsiveness and NO Indexes between Subjects with Pollen Allergy and Healthy

Controls

Compared with healthy controls, subjects with pollen allergy had lower values of $\mathrm{PC}_{20} \mathrm{AMP}(\mathrm{p}<0.01$ for season and $\mathrm{p}=0.014$ for out of season) and $\mathrm{PC}_{20}$ methacholine ( $p<0.001$ for both periods), and higher values of response plateaus to AMP ( $p<0.0001$ for season and $p=0.012$ for out of season) and J'aw ${ }_{\mathrm{NO}}(\mathrm{p}<0.0001$ for both periods) (table 2, fig. 2). The response plateau to methacholine was significantly higher in subjects with pollen allergy than in healthy controls during the pollen season only ( $\mathrm{p}=$ 0.015) (table 2). No significant differences were observed 


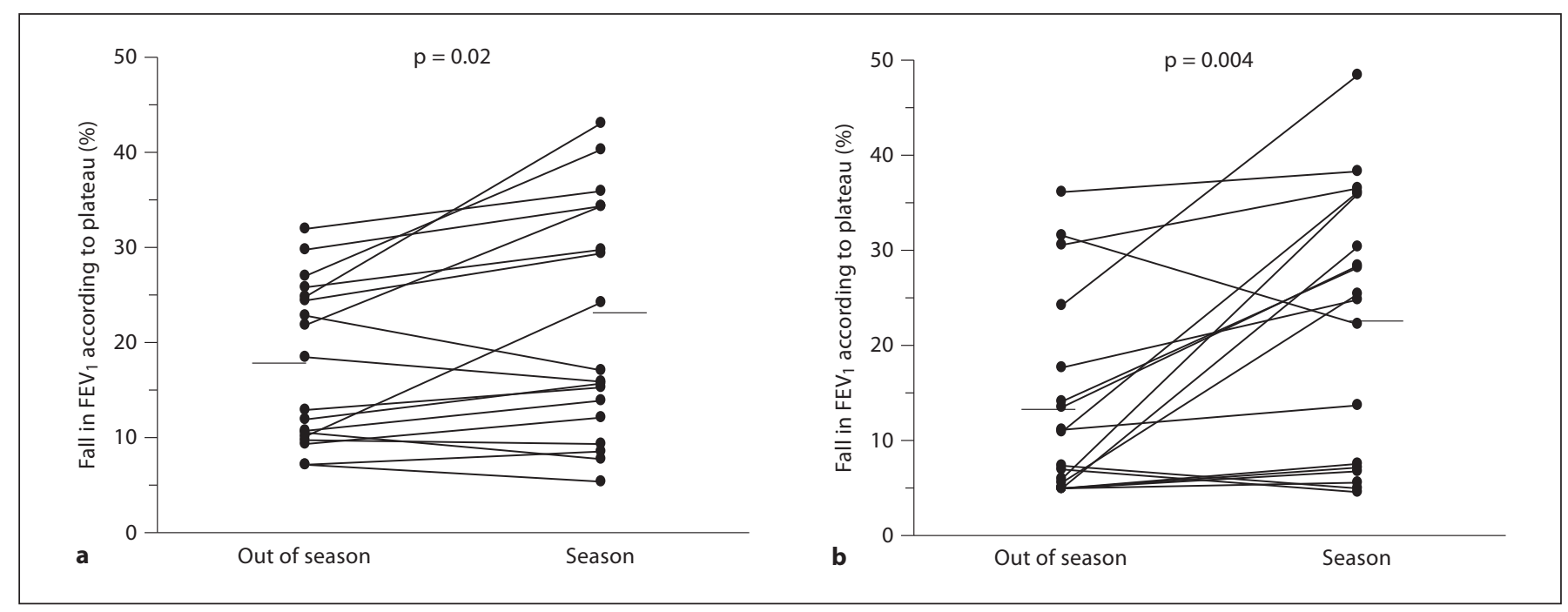

Fig. 3. Individual values for the response plateau to methacholine (a) and AMP (b) before and during the pollen season in subjects who showed plateaus in at least one period. Horizontal lines are means.

Table 3. Level of plateau and markers in exhaled air in subjects with allergic rhinitis and in those with asthma

\begin{tabular}{|c|c|c|c|c|}
\hline \multirow[t]{2}{*}{ Variable } & \multicolumn{2}{|l|}{ Asthma } & \multicolumn{2}{|l|}{ Allergic rhinitis } \\
\hline & out of season & during season & out of season & during season \\
\hline \multicolumn{5}{|l|}{ Plateau level, \% } \\
\hline Methacholine & $23.2(15.2-31.7)$ & $33.5(20.0-46.9)^{*}$ & $15.4(10.4-20.4)$ & $17.3(11.5-23.1)$ \\
\hline AMP & $13.6(5.0-23.4)$ & $26.9(12.2-41.6)^{*}$ & $13.2(6.0-20.4)$ & $20.1(11.9-28.3)^{*}$ \\
\hline \multicolumn{5}{|l|}{ Exhaled NO } \\
\hline J'aw $w_{\mathrm{NO}}, \mathrm{pl} / \mathrm{s}$ & $2,266(1,005-3,528)$ & $2,847(1,412-4,282)$ & $1,880(1,093-2,667)$ & $2,360(1,496-3,225)^{* *}$ \\
\hline $\mathrm{CA}_{\mathrm{NO}}, \mathrm{ppb}$ & $1.3(0.3-2.3)$ & $0.8(0.1-1.6)$ & $0.8(0.5-1.1)$ & $0.7(0.4-1.0)$ \\
\hline
\end{tabular}

Data are given as means and 95\% CI (in parentheses). ${ }^{*} \mathrm{p}<0.05$ vs. out of season; ${ }^{* *} \mathrm{p}<0.01$ vs. out of season.

between the two groups regarding $\mathrm{CA}_{\mathrm{NO}}(\mathrm{p}=0.17$ during the pollen season and $\mathrm{p}=0.51$ out of season).

\section{Modifications in Airway Responsiveness and NO \\ Indexes during the Pollen Season}

The mean $\mathrm{FEV}_{1}$ values for subjects with pollen allergy was 3.09 liters (95\% CI: $2.75-3.43$ ) out of season, compared with 3.04 liters (95\% CI: $2.7-3.37, \mathrm{p}=0.38)$ during the pollen season.

In the group with pollen allergy, methacholine and AMP $\mathrm{PC}_{20}$ values decreased significantly during the pollen season $(p=0.008$ for methacholine and $p=0.002$ for AMP, table 2). Pollen-induced changes in methacholine and $\mathrm{AMP} \mathrm{PC}_{20}$ values were not significantly different, the mean difference being 0.32 doubling concentrations ( $95 \%$ CI: -0.24 to 0.87 doubling concentrations, $\mathrm{p}=0.25$ ). Similar results were obtained when those subjects with censored $\mathrm{PC}_{20}$ values in both periods were excluded from the analysis (data not shown).

In the 18 subjects with pollen allergy who showed plateaus in at least one period, the response plateau to AMP increased from a mean of $13.4 \%$ (95\% CI: 8.2-18.5) out of season to $22.5 \%$ (95\% CI: $15.5-29.4, p=0.004$, fig. 3) during the pollen season; the response plateau to methacholine increased from $17.6 \%$ (95\% CI: 13.4-21.8) out of season to $21.8 \%$ (95\% CI: $15.7-27.9, \mathrm{p}=0.02)$ during the pol- 


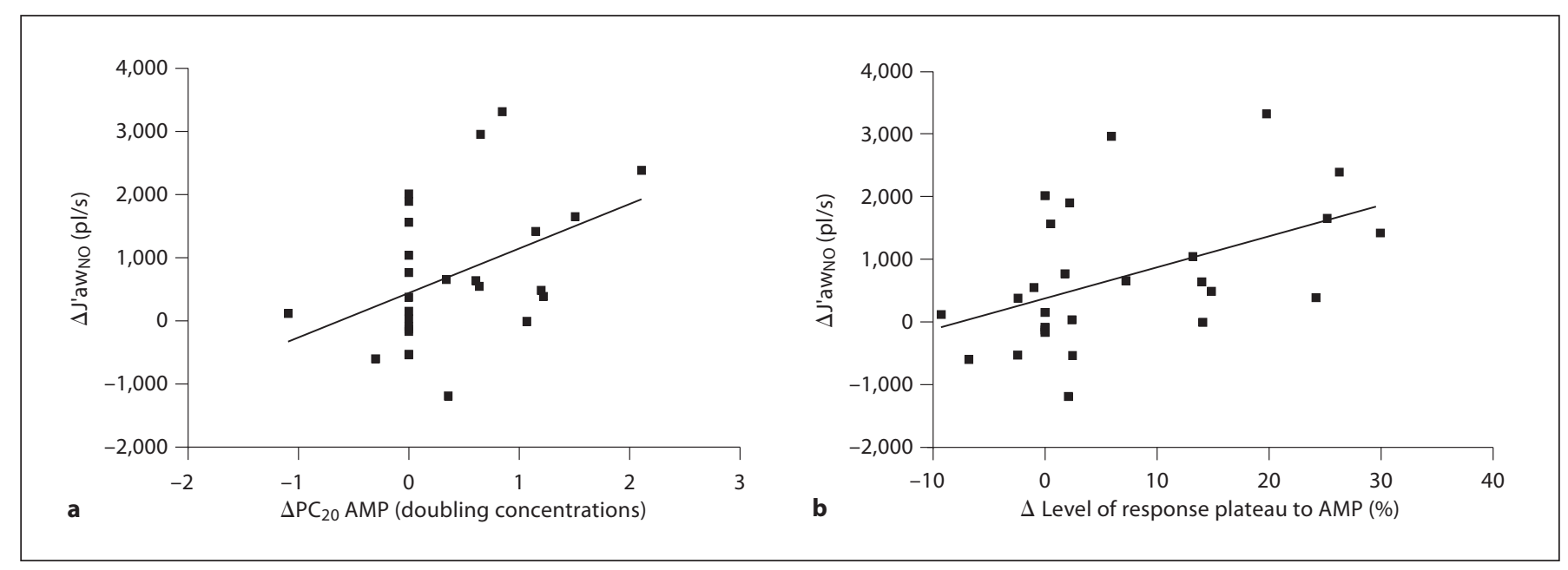

Fig. 4. Correlations between pollen-induced changes in J'aw ${ }_{N O}$ and either $\mathrm{AMP} \mathrm{PC}_{20}$ (a) or response plateau (b). Modifications of $\mathrm{PC}_{20}$ are expressed in terms of doubling concentrations [ $\log \mathrm{PC}_{20}$ out of season $-\log \mathrm{PC}_{20}$ in season)/log 2], whereas changes in the response plateau and $\mathrm{J}^{\prime} \mathrm{w}_{\mathrm{NO}}$ are expressed as values during the pollen season - values out of season $\left(\mathrm{r}=0.42, \mathrm{p}=0.03\right.$ for $\mathrm{PC}_{20} ; \mathrm{r}=0.48, \mathrm{p}=0.01$ for the response plateau).

len season (fig. 3). Pollen-induced changes in the response plateau to each bronchoconstrictor agent were not significantly different, the mean difference being 6.7\% (95\% CI: -2.2 to $15.6, \mathrm{p}=0.12$ ).

In the group with pollen allergy, natural pollen exposure increased J'aw ${ }_{\mathrm{NO}}(\mathrm{p}=0.003)$, but had no effect on $\mathrm{CA}_{\mathrm{NO}}(\mathrm{p}=0.12$, table 2 , fig. 2$)$.

\section{Differences in Pollen-Induced Changes in the Plateau} and Exhaled Markers between Subjects with Allergic

Rhinitis Alone and Those with Concomitant Asthma

Both in asthmatics and subjects with allergic rhinitis, the response plateau to each bronchoconstrictor agent and J'aw ${ }_{N O}$ values increased during the pollen season (table 3). Furthermore, the pollen-induced change in the response plateau with methacholine was significantly higher in the group with asthma than in the group with allergic rhinitis, the mean difference being 8.3\% (95\% CI: $2.3-14.3, \mathrm{p}=0.009$ ). By contrast, pollen-induced changes in both the response plateau to AMP and J'aw ${ }_{\mathrm{NO}}$ values were similar in the two groups, the mean difference being 6.4\% (95\% CI: $5.2-18.1, \mathrm{p}=0.26)$ and $9.53 \mathrm{pl} / \mathrm{s}$ ( $95 \%$ CI: -8.7 to $27.8, \mathrm{p}=0.29$ ), respectively.

\section{Correlations}

In subjects with pollen allergy, there was a weak correlation between $\mathrm{AMP} \mathrm{PC}_{20}$ values and J'aw $\mathrm{NO}$ (out of season, $r=-0.56, p=0.003$; season, $r=-0.50, p=0.008$ ), as well as between the response plateau to AMP and J'aw ${ }_{\mathrm{NO}}$ (out of season, $\mathrm{r}=0.54, \mathrm{p}=0.004$; season, $\mathrm{r}=0.42, \mathrm{p}=0.03$ ). Furthermore, there was a trend to a correlation between pollen-induced changes in J'aw ${ }_{\mathrm{NO}}$ and in responsiveness to $\operatorname{AMP}\left(\mathrm{r}=0.42, \mathrm{p}=0.03\right.$ for $\mathrm{PC}_{20}$ and $\mathrm{r}=0.48, \mathrm{p}=0.01$ for plateau; fig. 4). All these correlations were not significant for methacholine. No other correlations were detected.

\section{Discussion}

The results of the present study confirm that, in pollen-sensitive subjects with allergic rhinitis associated or not with intermittent asthma, natural exposure to pollen is associated with a significant increase in airway sensitivity (decreased $\mathrm{PC}_{20}$ value) to both methacholine and AMP, as well as with a significant increase in the response plateau to methacholine. The new findings are that natural pollen exposure in sensitized subjects is also associated with a significant increase in the response plateau identified with AMP and in J'aw ${ }_{\mathrm{NO}}$ without concomitant modifications in $\mathrm{CA}_{\mathrm{NO}}$. Furthermore, the response plateau to AMP and J'aw ${ }_{\text {NO }}$ values were significantly higher in subjects with pollen allergy than in healthy controls.

To the best of our knowledge, this is the first study designed to identify the effect of natural allergen exposure on the response plateau to AMP. Our results demonstrate that the allergen-induced increase in the plateau to AMP is of similar magnitude to that detected with methacho- 
line. However, allergen-induced changes in methacholine and $\mathrm{AMP}$ responsiveness $\left(\mathrm{PC}_{20}\right.$ and response plateau) were not significantly related. Therefore, although the global consequences of natural allergen exposure on the responsiveness to direct and indirect bronchoconstrictors are quantitatively similar, the effects on airway responsiveness to each agonist are not proportional in each subject.

We deliberately studied patients with intermittent asthma or allergic rhinitis without asthma in order to detect a maximal response plateau in a significant number of subjects. It could be argued, however, that the effect of natural allergen exposure on the maximal response plateau might be different in subjects with greater asthma severity. In addition, although pollen-induced increases in the response plateau to methacholine and AMP were detected both in subjects with asthma and in nonasthmatic subjects with allergic rhinitis, these were more pronounced in asthmatics. However, the number of subjects in each group was small and a type 2 error cannot be ruled out.

Our results demonstrate that natural allergen exposure is associated with a selective increase in $\mathrm{NO}$ of bronchial origin. Additionally, although allergen-induced changes in J'aw ${ }_{N O}$ were detected both in subjects with asthma and in those with allergic rhinitis alone, these were more pronounced in nonasthmatics. Since it has been postulated that exhaled NO may be a marker of airway inflammation [8], the increase in J'aw ${ }_{\mathrm{NO}}$ following natural allergen exposure may be explained by an increase in the inflammatory mediators needed to increase the expression of inducible NO synthase. Therefore, the results of our study suggest that the proinflammatory effect of allergen exposure in sensitized subjects is predominantly expressed in the airways, and that an allergeninduced increase in bronchial inflammation is not sufficient to induce asthmatic symptoms. However, it has been suggested that the original two-compartment model developed by Tsoukias and George [19] to describe bronchial and alveolar sites of NO concentration may have led to overestimation of $\mathrm{CA}_{\mathrm{NO}}$ values. In the present study, $\mathrm{CA}_{\mathrm{NO}}$ values were corrected using the fixed correction factor recommended by Condorelli et al. [20] for the flow rates used in our subjects. However, during the pollen season the correction factor for axial NO back-diffusion may be smaller due to an allergen-induced bronchoconstriction [22] with a subsequent reduction in the cross-sectional area available for back-diffusion of NO. This would be associated with an underestimation of $\mathrm{CA}_{\mathrm{NO}}$ levels during the pollen season and, therefore, with greater differences between the two study periods. We do not believe, however, that our findings could have been influenced by this technical factor because the baseline $\mathrm{FEV}_{1}$ values in our patients during the two study periods were similar.

The presence of airway hyperresponsiveness to AMP and increased J'aw ${ }_{\mathrm{NO}}$ in our subjects with pollen allergy, even when these parameters were obtained out of the pollen season, suggests that airway inflammation is present even when patients are not exposed to the relevant allergens. However, this study has some limitations that are important to consider. Firstly, our patients with pollen allergy were significantly older than healthy controls. Therefore, although the effect of age on AMP responsiveness has not been studied, we cannot exclude the possibility that differences in these parameters between the two groups might be explained, at least in part, by differences in age. Secondly, it has recently been reported [23] that NO concentration measured at 50 $\mathrm{ml} / \mathrm{s}$ and $\mathrm{CA}_{\mathrm{NO}}$, but not bronchial NO production, increases with age $\geq 60$ years in normal control subjects. Thus, differences in J'aw ${ }_{\mathrm{NO}}$ between subjects with pollen allergy and healthy controls cannot be explained by differences in age. Thirdly, the effect of natural pollen exposure on airway responsiveness, $\mathrm{CA}_{\mathrm{NO}}$ and J'aw ${ }_{\mathrm{NO}}$ were identified comparing values during the pollen season and out of season. It is possible that the inclusion of a control group of subjects with nonatopic asthma might increase the relevance of our observations. This should be investigated in future studies. Finally, our healthy controls were studied on one occasion only and, therefore, the reproducibility of our results in this population is unknown.

In summary, our current observations have shown an increase in both the response plateau and J'aw ${ }_{\mathrm{NO}}$ in subjects with pollen allergy compared with healthy controls. In subjects with pollen allergy, both parameters increased significantly following natural allergen exposure. These results suggest that natural allergen exposure in sensitized subjects induces inflammatory changes in the airways (but not in the lung periphery) and modifications in the shape of the concentration-response curve to direct and indirect agonists.

\section{Acknowledgements}

The authors wish to thank Regiduria de Sanidad (Seccion de Programas de Salud) from the Ayuntamiento de Valencia for providing data on atmospheric pollen counts, and Diater Laboratorios (Madrid, Spain) for help and collaboration. The technical assistance of Rocio Rojas and Ana Lucas is gratefully acknowledged. 


\section{References}

1 Woolcock AJ: What is bronchial hyperresponsiveness from the clinical standpoint?: in Page CP, Gardiner PJ (eds): Airway hyperresponsiveness: is it really important for asthma? Oxford, Blackwell, 1993, pp 1-9.

$\checkmark 2$ Sterk PJ, Bel EH: Bronchial hyperresponsiveness: the need for a distinction between hypersensitivity and excessive airway narrowing. Eur Respir J 1989;2:267-274.

$\checkmark 3$ Bel EH, Timmens MC, Zwinderman AH, et al: The effect of inhaled corticosteroids on the maximal degree of airway narrowing to methacholine in asthmatic subjects. Am Rev Respir Dis 1991;143:109-113.

4 Polosa R, Ng WH, Crimi N, Vancheri C, Holgate ST, Church MK, Mistretta A: Release of mast-cell-derived mediators after endobronchial adenosine challenge in asthma. Am J Respir Crit Care Med 1995;151:624-629.

5 Van den Berge M, Meijer RJ, Kerstjens HAM, et al: $\mathrm{PC}_{20}$ adenosine $5^{\prime}$-monophosphate is more closely associated with airway inflammation in asthma than $\mathrm{PC}_{20}$ methacholine. Am J Respir Crit Care Med 2001;163:15461550 .

6 Alving K, Weitzberg E, Lundberg JM: Increased amount of nitric oxide in exhaled air of asthmatics. Eur Respir J 1994;6:13681370.

$\checkmark 7$ Jatakanon A, Lim S, Kharitonov SA, Chung KF, Barnes PJ: Correlation between exhaled nitric oxide, sputum eosinophils, and methacholine responsiveness in patients with mild asthma. Thorax 1998;53:91-95.

8 Barnes PJ, Kharitonov SA: Exhaled nitric oxide: a new lung function test. Thorax 1996; 51:233-237.
-9 Matsumoto H, Niimi A, Jinnai M, et al: Association of alveolar nitric oxide levels with pulmonary function and its reversibility in stable asthma. Respiration 2011;81:311-317.

10 George SC, Hogman M, Permutt S, Silkoff PE: Modeling pulmonary nitric oxide exchange. J Appl Physiol 2004;96:831-839.

11 Prieto L, López M, Bertó JM, Peris A: Modi fication of concentration-response curves to inhaled methacholine after the pollen season in subjects with pollen induced rhinitis. Thorax 1994;49:711-713.

12 Prieto L, Bertó JM, Gutiérrez V, Tornero C Effect of inhaled budesonide on seasonal changes in sensitivity and maximal response to methacholine in pollen-sensitive asthmatic subjects. Eur Respir J 1994;7:18451851.

13 Henriksen AH, Sue-Chu M, Holmen TL, Langhammer A, Bjermer L: Exhaled and nasal NO levels in allergic rhinitis: relation to sensitization, pollen season and bronchial hyperresponsiveness. Eur Respir J 1999;13: 301-306.

- 14 Prieto L, Uixera S, Gutiérrez V, Bruno L: Modifications of airway responsiveness to adenosine 5'-monophosphate and exhaled nitric oxide concentrations after the pollen season in subjects with pollen-induced rhinitis. Chest 2002;122:940-947.

15 Ajuntament de Valencia, Regidoria de Sanitat, Servicio de Sanidad. Calendario polínico de Valencia. http://WWW.Valencia.es/ayuntamiento/aerobiologia.nsf. Accessed, June 15,2010
16 American Thoracic Society: Standardization of spirometry, 1987 update. Am Rev Respir Dis 1987;136:1285-1298.

17 American Thoracic Society: Guidelines for methacholine and exercise challenge testing, 1999. Am J Respir Crit Care Med 2000;161: 309-329.

18 ATS/ERS: Recommendations for standardized procedures for the online and offline measurement of exhaled lower respiratory nitric oxide and nasal nitric oxide. Am J Respir Crit Care Med 2005;171:912-930.

19 Tsoukias MM, George SC: A two-compartment model of pulmonary nitric oxide exchange dynamics. J Appl Physiol 1998;85: 653-666.

20 Condorelli P, Shin HW, Aledia AS, Silkoff PE, George SC: A simple technique to characterize proximal and peripheral nitric oxide exchange using constant flow exhalations and an axial diffusion model. J Appl Physiol 2007; 102:417-425

21 Prieto L, Esnal S, López V, Barato D, Rojas R, Marín J: Maximal response plateau to adenosine 5'-monophosphate in asthma. Relationship with the response to methacholine, exhaled nitric oxide, and exhaled breath condensate $\mathrm{pH}$. Chest 2009;135:1521-1526.

22 Verbanck S, Kerckx Y, Schuermans D, Vincken M, Paira M, Van Muylem A: Effect of airways constriction on exhaled nitric oxide. J Appl Physiol 2008;104:909-911.

23 Gelb AF, George SC, Camacho F, Fraser C, Taylor CF, Shakkottai S: Increased nitric oxide concentrations in the small airway of older normal subjects. Chest 2011;139:368-375. 